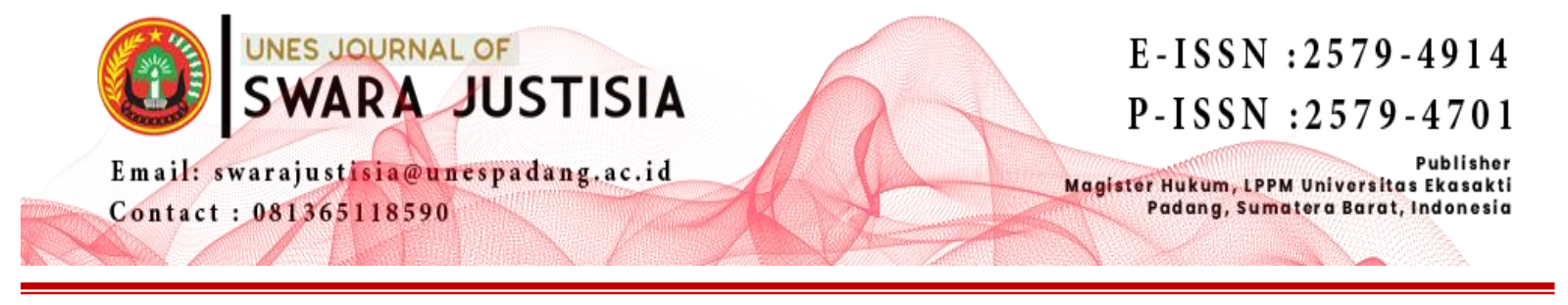

\title{
PENEGAKAN HUKUM TINDAK PIDANA PEMANFAATAN RUANG LAUT SECARA MENETAP TANPA IZIN OLEH DITPOL AIRUD POLDA SUMBAR
}

\author{
Irwandi Idham \\ Program Magister Ilmu Hukum, Universitas Ekasakti, Padang, Indonesia \\ Email: irwandiidham73@gmail.com
}

\begin{abstract}
Law Enforcement Against Criminal Acts of Permanent Utilization of Marine Space Without Permit by the West Sumatra Regional Police Directorate of Polairud is by conducting investigations into criminal acts suspected of violating the provisions of Article 49 and Article 75 of Law of the Republic of Indonesia Number 32 of 2014 concerning Marine, namely the permanent use of marine space without permission. This regulation in West Sumatra is supported by West Sumatra Governor Regulation Number 51 of 2018 concerning Procedures for Granting Location Permits and Coastal Water Management Permits. The object here is Sirandah Island which is located in the city of Padang. Management of the island of Sirandah without official permission from the local government is a maritime crime. Obstacles Faced in Law Enforcement Against Criminal Acts of Sedentary Utilization of Marine Space Without Permit by the West Sumatra Police Ditpolairud are problems of law enforcement objects that are difficult to penetrate the law. Weak coordination between law enforcers can lead to overlapping of respective authorities and policies. Uncoordinated law enforcement is one of the obstacles in prosecuting crimes against the use of marine space permanently without a permit.
\end{abstract}

Keywords: Law Enforcement, Crime, Utilization of marine space, Investigation

\begin{abstract}
ABSTRAK
Penegakan Hukum Terhadap Tindak Pidana Pemanfaatan Tetap Ruang Laut Tanpa Izin oleh Direktorat Polairud Polda Sumbar adalah dengan melakukan penyidikan terhadap tindak pidana yang diduga melanggar ketentuan Pasal 49 dan Pasal 75 Undang-Undang Republik Indonesia Nomor 32 Tahun Tahun 2014 tentang Kelautan, yaitu pemanfaatan ruang laut secara tetap tanpa izin. Peraturan di Sumatera Barat ini didukung oleh Peraturan Gubernur Sumatera Barat Nomor 51 Tahun 2018 tentang Tata Cara Pemberian Izin Lokasi dan Izin Pengelolaan Perairan Pesisir. Objek di sini adalah Pulau Sirandah yang terletak di kota Padang. Pengelolaan Pulau Sirandah tanpa izin resmi dari pemerintah setempat merupakan kejahatan maritim. Kendala Yang Dihadapi Dalam Penegakan Hukum Terhadap Tindak Pidana Pemanfaatan Ruang Laut Tanpa Izin oleh Ditpolairud Polda Sumbar adalah permasalahan objek penegakan hukum yang sulit ditembus hukum. Koordinasi yang lemah antar penegak hukum dapat menyebabkan tumpang tindih kewenangan dan kebijakan masing-masing. Penegakan hukum yang tidak terkoordinasi merupakan salah satu kendala dalam penuntutan tindak pidana pemanfaatan ruang laut secara permanen tanpa izin.
\end{abstract}

Kata Kunci: Penegakan Hukum, Kejahatan, Pemanfaatan Ruang Laut, Penyidikan 


\section{PENDAHULUAN}

Penelitian ini mengkaji tentang penegakan hukum terhadap tindak pidana kelautan yang berbentuk pemanfaatan ruang laut secara menetap tanpa izin oleh Ditpolairud Polda Sumbar. Hal ini sesuai yang diatur pada Pasal 47 dan Pasal 49, Undang Undang Nomor 32 Tahun 2014 tentang Kelautan, dinyatakan bahwa adanya sanksi bagi pelanggar norma tsb, yang satu adalah perbuatan yang dikenakan denda administratif, yang berupa : peringatan tertulis; penghentian sementara kegiatan; penutupan lokasi; pencabutan izin; dan atau denda administrasi; sedangkan sanksi bagi perbuatan lainnya berupa Hukuman Penjara dan denda yang cukup berat.

Ditinjau dari segi konfigurasinya wilayah Indonesia merupakan kawasan laut yang ditaburi pulau-pulau, baik besar maupun kecil dengan jumlah sekitar 17.504 pulau. Luas wilayah Indonesia yang merupakan negara kepulauan (archipelagic state) tersebut adalah sekitar 7,7 juta Km2. Duapertiga dari luas wilayahnya yaitu 5,8 juta Km2 adalah lautan yang mengandung potensi sumber daya kelautan yang melimpah dan mempunyai nilai sangat strategis bagi kehidupan nasional bangsa Indonesia. Dengan garis pantai sepanjang lebih dari $81.000 \mathrm{Km}$, maka Indonesia menjadi negara yang memiliki pulau terpanjang kedua di dunia setelah Kanada. ${ }^{1}$

Letak geografis Indonesia yang berada di antara Benua Asia dan Australia serta di antara Samudera Hindia dan Samudera Pasifik telah menempatkan Indonesia pada posisi strategis ditinjau dari segi ekonomi, politik, sosial budaya dan pertahanan keamanan. Selain itu, posisi dan sumber daya kelautan tersebut juga menempatkan Indonesia menjadi sangat penting bagi negara-negara dari berbagai kawasan. Namun posisi strategis ini selain merupakan peluang sekaligus kendala bagi bangsa Indonesia dalam mewujudkan cita-cita bangsa. $^{2}$

Kendala, ancaman atau permasalahan dapat timbul karena sebagai negara yang memiliki sumber daya kelautan yang sangat kaya dan beragam, maka sangat terbuka kemungkinan terpancingnya pihak-pihak tertentu untuk memanfaatkan secara ilegal sumber daya kelautan tersebut. Terlebih lagi mengingat tidak semua negara mempunyai laut yang cukup bagi kepentingan ekonominya, sehingga mereka berupaya untuk mendapatkan sumber kekayaan alam dari wilayah laut secara tidak legal ${ }^{3}$. Kemungkinan ini tidak saja dapat mengganggu stabilitas keamanan di laut, tetapi juga dapat menimbulkan konflik dengan negara lain, bahkan tidak mustahil menjadi perang terbuka antar negara.

Keadaan tersebut sangat berpotensi mengancam dan merugikan kepentingan Indonesia, khususnya kepentingan Indonesia atas wilayah lautnya. Padahal laut mempunyai peranan dan arti yang sangat signifikan bagi bangsa Indonesia, khususnya bagi pembangunan nasionalnya mengingat laut mempunyai fungsi-fungsi, antara lain; ${ }^{4}$

(i) sebagai media pemersatu,

\footnotetext{
${ }^{1}$ Evi Banowati, Geografis Indonesia, Ombak, Jakarta, 2015, hlm 1

2 Didik Heru Purnomo, Pengamanan Wilayah Laut Indonesia, Jurnal Hukum Internasional, Desember 2004, hlm. 27

${ }^{3}$ Dicky R Munaf, Kajian Sistem Operasi Tersinergi Bakamla Sesuai Undang-Undang Nomor 32 Tahun 2014 tentang Kelautan 2015, Jurnal Sosioteknologi, KKIK ITB, Bandung, 2015

${ }^{4}$ Bakamla, Pokok-pokok Pikiran Tentang Keamanan Laut, Markas Besar TNI Angkatan Laut, Jakarta, 2002, hlm. 56
} 
(ii) sebagai media perhubungan baik antar pulau maupun antar Negara,

(iii) sebagai media sumber daya baik hayati, non hayati maupun buatan,

(iv) sebagai media pertahanan keamanan dan,

(v) sebagai media dan sarana untuk membangun pengaruh terhadap negaranegara lain dalam rangka penangkalan.

Secara formal norma pidana di bidang kelautan adalah sederajat dengan undang undang lainnya, Norma pidana dibidang kelautan tsb, adalah amat sempit akibat tidak meliputi tindakan atau perbuatan hukum oleh suatu korporasi atau badan usaha yang juga dapat dikategorikan sebagai salah satu pelaku tindak pidana khusus dalam sistem penegakan hukum Indonesia.

Kesulitan yang ada selama ini adalah tidak terdeteksinya terjadinya tindak pidana kelautan. Hal ini pernah terjadi ketika Ditpolairud Polda Sumbar mendeteksi adanya penggunaan dan pengelolaan ruang laut yang tidak berizin terhadap pulau Sirandah yang terletak di wilayah kota Padang. Berdasarkan latar belakang pemikiran di atas, maka permasalahan adalah Penegakan hokum pada tindak pidana kelautan dan kendala yang ada dalam usaha tersebut.

\section{METODE PENELITIAN}

Spesifikasi penelitian adalah deskriptif analitis, dengan metode pendekatan yuridis normative didukung oleh yuridis empiris. Jenis data yang digunakan adalah data sekunder. Data sekunder diperoleh dari studi dokumen dan studi kepustakaan. Data yang diperoleh kemudian dianalisa secara kualitatif.

\section{PEMBAHASAN}

\section{A. Penegakan Hukum Terhadap Tindak Pidana Pemanfaatan Ruang Laut Secara Menetap Tanpa Izin Oleh Ditpolairud Polda Sumbar}

Penegakan hukum dalam bidang Kelautan dirasakan sangat diperlukan dalam mengatasi berbagai permasalahan yang timbul di lapangan, hal ini sangat perlu dalam penegakan hukum nasional Indonesia untuk wilayah laut terutama kedaulatan teritorialnya. Secara umum pengertian penegakan hukum menurut Satjipto Rahardjo adalah suatu usaha untuk mewujudkan ide-ide menjadi kenyataan, sedangkan Soejono Soekanto dengan mengutip pendapat Purnadi Purbacaraka mengatakan bahwa penegakan hukum adalah kegiatan menyerasikan hubungan nilai-nilai yang mantap dan mengejahwantahkan serta sikap tindak sebagai rangkuman penjabaran nilai tahap akhir untuk menciptakan (social engineering), memelihara dan mempertahankan (control) perdamaian pergaulan hidup. Lebih lanjut menurut Soewardi M pengertian umum penegakan hukum adalah kegiatan untuk melaksanakan atau memberlakukan ketentuan. Lebih jauh lagi dijelaskan bahwa sistem hukum yang baik adalah menyangkut penyerasian antara nilai dengan kaidah serta dengan perilaku nyata. ${ }^{5}$

Berdasarkan dari segi hirarki dan jenis materi muatan ketentuan yang diatur dalam undang undang tentang kelautan, maka terdapat hubungan dengan materi muatan ketentuan yang terdapat di berbagai peraturan pemerintah sebagai pelaksanaan berbagai

\footnotetext{
${ }^{5}$ Raida L. Tobing dan Sriwulan Rios, Penegakan Kedaulatan dan Penegakan Hukum Di Ruang Udara, Jurnal Penelitian Hukum De Jure, AsosiasiPeneliti Hukum Indonesia, Vol 01 N0. 2, 1998, hal 49
} 
undang undang antara lain peraturan pemerintah tentang ketelitian peta tata ruang; pelaksanaan informasi geospasial; pengelolaan kawasan khusus; pengelolaan dan pemanfaatan wilayah pesisir dan pulau pulau kecil; angkutan di perairan; pengelolaan usaha pertambangan termasuk juga pelestarian lingkungan hidup. Di Sumatera Barat terdapat Peraturan Gubernur Sumatera Barat Nomor 51 tahun 2018 Tentang Tata Cara Pemberian Izin Lokasi Dan Izin Pengelolaan Perairan Pesisir. Ketentuan tindak pidana kelautan yang terdapat dalam undang undang kelautan harus di dukung oleh berbagai peraturan daerah sebagai pelaksanaannya.

Ditpolairud Polda Sumbar telah melakukan penegakan hukum terhadap tindak pidana kelautan dengan cara melakukan penyidikan terhadap perbuatan pidana yang disangkakan melanggar ketentuan Pasal 49 dan pasal 75 Undang-Undang Republik Indonesia Nomor 32 tahun 2014 tentang Kelautan. Izin mendirikan bangunan adalah Produk Hukum yang berisi persetujuan atau perizinan yang dikeluarkan oleh Kepala Daerah setempat dan wajib dimiliki atau diurus oleh pemilik bangunan yang ingin membangun, merobohkan /mengurangi luas ataupun renovasi suatu bangunan dimana tujuan dari IMB tersebut adalah untuk menciptakan tata letak bangunan yang aman dan sesuai dengan peruntukan lahan. Pemerintah Kota (Pemkot) Padang, Sumatera Barat, menegaskan telah menutup objek wisata pulau yang tidak memiliki izin atau ilegal. Objek wisata pulau yang bakal ditutup itu salah satunya Pulau Sirandah, yang sebelumya sempat terjadi peristiwa kebakaran salah satu penginapan di sana. Pengelolaan pulau Sirandah dengan tidak memiliki izin resmi dari pemerintah daerah merupakan suatu tindak pidana kelautan. Penegakan hukum dilakukan atas Tindak Pidana Pemanfaatan Ruang Laut dan tindak Pidana Pemanfaatan serta Pengelolaan Wilayah Pesisisr dan Pulau Pulau kecil yang dilakukan sejak tahun 2016 oleh Tersangka, terhadap Pengelolaan Wilayah Pulau Sirandah untuk Pariwisata yang diduga tidak memiliki izin lokasi dan izin Pengelolaan sebagaimana yang dimaksud dalam Pasal 49 Undang-Undang Republik Indonesia No. 32 Tahun 2014 tentang Kelautan Juncto Pasal 75 Undang-Undang Republik Indonesia No. 1 Tahun 2014 tentang Perubahan atas Undang-Undang Republik Indonesia No. 27 Tahun 2007 tentang Pengelolaan Wilayah Pesisir dan Pulau-Pulau Kecil.

Adapun perbuatan yang dilakukan adalah melakukan Pembangunan dermaga, penginapan, restoran, arena bermain dan arena bermain water boom di Pulau Sirandah tanpa izin dari pemerintah setempat. Pembangunan berbagai fasilitas tersebut termasuk pemanfaatan ruang, Adapun ruang yang dimanfaatkan adalah ruang darat dan ruang laut. Yang termasuk pemanfaatan ruang darat adalah pembangunan yang dilakukan di daratan pulau seperti penginapan, restoran, arena bermain, taman dan lain sebagainya. Sedangkan yang termasuk pemanfaatan ruang laut adalah pembangunan yang menggunakan wilayah periaran/laut seperti pembangunan dermaga atau pembangunan arena bermain berupa water boom yang menjorok kelaut.

Alur pikiran yang terkandung dalam norma pidana kelautan tersebut, adalah jika subyek atau pelaku perbuatan yang terkait langsung maupun tidak langsung dengan pemanfaatan ruang kelautan, semata adalah orang seorang dengan sebutan setiap orang. Terkadang unsur subyek dalam tindak pidana ini juga dilakukan oleh koorporasi seperti pada perkara pengelolaan pulau Sirandah. Dimana subyek dari tindak pidana ini adalah 
Koorporasi yaitu PT. MGSB HOLDING LTD yang diwakili oleh Direktur dan Komisarisnya.

Obyek yang menjadi tujuan penghukumannya adalah ketiadaan kepemilikan izin lokasi. Kronologis pengelolaan Pulau Sirandah tersebut adalah sebelumnya pada tahun 2015 Direktur Utama PT. Multi Wisata Bahari membuat perjanjian kerja sama dengan ninik mamak 8 Suku di Kelurahan Sungai Pisang Kota Padang perihal pengelolaan Pulau Sirandah untuk usaha Pariwisata. Kerja sama tersebut dilakukan dengan surat perjanjian di Notaris. Pada tahun 2015 tersebut pengelolaan Pulau Sirandah untuk usaha Pariwisata tersebut belum berjalan. Pada saat itu baru dilakukan pembersihan Lokasi dan belum ada pembangunan yang dilakukan.

Pada tahun 2016 Direktur Utama PT. Multi Wisata Bahari bekerja sama dengan PT. MGSB Holdings dengan Direktur Utamanya Tomi Devisa selaku Investor untuk melakukan pembangunan dan pengelolaan dalam rangka usaha Pariwisata dengan Surat perjanjian di Notaris. Setelah kerjasama tersebut pengelolaan Pulau Sirandah tersebut dikelola oleh PT. MGSB Holdings karena Pemilik modal adalah PT. MGSB Holdings. Sejak 1 Januari 2017 dimulai lah pembangunan yang telah direncanakan tersebut. pembangunan dimulai dari Dermaga setelah itu berlanjut kepada pembangunan yang lainnya.

Seiring dengan pengerjaan proyek pembangunan Resort Pulau Sirandah tersebut usaha wisata sudah mulai jalan tetapi belum ramai dan kebanyakan hanya tamu-tamu camping. Pada bulan September tahun 2017 pengerjaan pembangunan proyek Resort Pulau Sirandah dihentikan dikarenakan permasalahan pembayaran proyek yang belum lunas. Pada bulan Januari sampai dengan bulan Maret tahun 2018 Pengelolaan Pulau Sirandah tersebut diambil alih oleh masyarakat Sungai Pisang dikarenakan jatah bagi hasil hak masyarakat Sungai Pisang belum diberikan oleh Pujo Hartoyo selaku Direktur PT. Multi Wisata Bahari.

Pada saat diambil alih masyarakat pengelolaan keuangan juga di kuasai oleh Kelompok masyarakat. Setelah jatah bagi hasil hak masyarakat Sungai Pisang tersebut dirasa sudah cukup maka pengelolaan pulau pada tanggal 1 April tahun 2018 diambil alih oleh sdr. Pujo Hartoyo selaku PT. Multi Wisata Bahari. Sedangkan dari Pihak dari PT. MGSB Holdings sama sekali tidak ada respon karena di PT. MGSB Holding sendiri juga terjadi permasalahan dana/modal investasi.

Pembangunan Water Boom di Pulau Sirandah merupakan pembangunan yang tidak memiliki Izin, Lokasi Pembangunan Water Boom di Pulau Sirandah tersebut adalah di pinggir pantai Pulau Sirandah tersebut. Bangunannya dibuat di pinggir pantai dan seluncur nya menjorok kelaut. Pembangunan Resort di pulau Sirandah tersebut ada menggunakan/ memanfaatkan Ruang laut yaitu pembangunan dermaga dan Waterboom. Yang mana pembangunan tersebut dilakukan di pinggir pantai dan menjorok kelaut, Pembangunan di Pulau Sirandah tersebut yang menggunakan/memanfaatkan Ruang laut seperti pembangunan dermaga dan water boom tidak ada memiliki Izin Lokasi dari Pejabat yang berwenang. Semua pembangunan di Pulau Sirandah tersebut baik yang dibangun di atas pulau maupun yang dibangun memanfaatkan ruang laut sama sekali tidak ada izin dari Pejabat yang berwenang. 
Tidak ada surat atau dokumen yang Sah yang menyatakan pulau Sirandah tersebut adalah tanah ulayat masyarakat Salapan Suku Kel. Sungai Pisang. Pulau Sirandah tersebut hanya diakui oleh kantor KAN (kerapatan Adat Nagari) Bungus Teluk Kabung secara turun temurun sebagai tanah ulayat masyarakat Salapan Suku Kel. Sungai Pisang. Sampai saat ini dokumen alas hak tentang kepemilikan Pulau Sirandah belum diterbitkan oleh kantor KAN (kerapatan Adat Nagari) Bungus Teluk Kabung.

Penafsiran yang mungkin berkembang atas fungsi normatif ketentuan pidana di bidang kelautan tersebut, adalah permasalahan status hukum kepemilikan izin lokasi dengan pertanyaan yang masih tersisa apakah izin lokasi dimaksud adalah merupakan bagian terpisah atau terintegrasi dengan izin izin lainnya misalnya izin usaha penguasaan dan pengusahaan perairan di wilayah pulau pulau kecil. Juga apakah izin usaha perikanan laut dan izin usaha pertambangan khusus mineral minyak dan gas bumi atau panas bumi adalah juga menjadi bagian dari izin lokasi dimaksud? Juga sejauh mana batasan kewenangan antara pemerintah pusat dan daerah terkait dengan izin izin yang telah ada selain izin lokasi yang dimaksud dalam undang undang tentang Kelautan .

Perbedaan tentang izin lokasi dengan izin izin lain misalnya izin lingkungan yang terbit dalam pengelolaan usaha perkebunan dan kehutanan, serta pertambangan mineral dan batu bara, maupun perikanan laut, dari sudut kewenangan lembaga penerbit izin maupun persyaratan teknis pelaksanaan/operatif yang harus dipenuhi oleh pemegang atau penerima izin adalah urgen demi kejelasan dan kepastian hukum yang juga menjadi perhatian umum. Oleh karena itu disatu segi bahwa harapan dan aspirasi masyarakat umum adalah agar peraturan pemerintah atau peraturan pelaksanaan dari undang undang tentang kelautan, tetap konsisten dengan tujuan utama meningkatkan pemerataan kesejahteraan masyarakat, seiring peningkatan laju pertumbuhan ekonomi nasional serta ditunjang dengan penyelenggaraan administrasi pemerintahan yang baik, yang justru terlebih dahulu dalam Undang Undang Tentang Administrasi Pemerintahan, telah meletakkan kerangka pikir dan perbuatan yang patut atau taat asas dalam penerbitan suatu keputusan administrasi oleh badan atau pejabat administrasi pemerintahan itu sendiri.

Selain kasus pengelolaan pulau Sirandah yang tidak memiliki izin dan kalau tetap dilanjutkan eksploitasinya dikhawatirkan akan merusak ekosistem laut sekitar pulau sirandah, Ditpolairud juga melakukan penegakan hukum terhadap beberapa pulau lain yang dikelola tanpa izin salah satunya adalah pulau Aweira di Kepulauan Mentawai. Pada pulau Aweira tersebut dilakukan pembangunan resort dan penginapan tanpa izin lokasi. Namun proses penyelidikan ini tidak dilanjutkan sampai sekarang. Pembangunan resort yang dilakukan dihentikan karena persoalan manajemen perusahaan pengelola. Sehingga karena keadaan tersebut penyelidikan juga tidak dilanjutkan.

\section{B. Kendala Yang Dihadapi Dalam Penegakan Hukum Terhadap Tindak Pidana Pemanfaatan Ruang Laut Secara Menetap Tanpa Izin Oleh Ditpolairud Polda Sumbar}

Pada penegakan hukum terhadap kejahatan yang diatur dalam tindak pidana kelautan dalam hal ini berbentuk penyidikan terhadap perbuatan pemanfaatan ruang laut secara menetap tanpa izin maka masih ditemui berbagai hambatan dalam usaha penegakan hukum tersebut. Adapun kendala yang dialami diantaranya adalah permasalahan obyek 
Penegakan Hukum yang sulit ditembus hukum. Obyek yang dimaksud disini adalah pelaku yang terlibat dalam kejahatan pemanfaatan ruang laut secara menetap tanpa izin yaitu pelaku yang menjadi otak dari kegiatan tersebut. Terutama dalam hal ini adalah oknum Pejabat Negara dan oknum Aparat Penegak Hukum yang membeking kegiatan tersebut. Serta pelaku yang nerupakan pengusaha dengan modal kekayaan besar. Pelaku pada tindak pidana pemanfaatan ruang laut secara menetap tanpa izin adalah koorporasi yang melakukan pengelolaan terhadap ruang laut tersebut.

Kendala selanjutnya adalah Lemahnya Koordinasi Antar Penegak Hukum dapat menimbulkan tumpang tindih kewenangan dan kebijakan masing masing, sehingga sangat rawan menimbulkan konflik kepentingan. Penegakan hukum yang tidak terkoordinasi merupakan salah satu kendala dalam penindakan kejahatan pemanfaatan ruang laut secara menetap tanpa izin. Kurangnya koordinasi yang efektif dan efisien antara berbagai Instansi yang terkait dalam penegakan hukum pemanfaatan ruang laut secara menetap tanpa izin menyebabkan sulitnya dilakukan penindakan terhadap pelanggar ketentuan tersebut. Dimana terdapat berbagai Instansi yang terkait yang berada dalam satu mata rantai penegakan hukum tindak pidana pemanfaatan ruang laut secara menetap tanpa izin yang sangat menentukan proses penegakan hukum diantaranya Dinas Kelautan dan Perikanan, Kepolisian Republik Indonesia, TNI-Angkatan Laut, Kejaksaan Negeri, Kementerian Hukum dan Ham Ditjen Keimigrasian, Kemeterian Perhubungan Ditjen Perhubungan Laut, Kementerian Keuangan Ditjen Bea dan Cukai, dan Pemerintah Daerah Provinsi/Kabupaten/Kota. Diluat daripada instansi tersebut ada masyarakat adat yang berperan dalam proses penegakan hukum. Karena Pada undang undang Kelautan diatur tentang pengakuan terhadap pengelolaan yang dilakukan oleh masyarakat adat. Koordinasi antar berbagai Instansi tersebut sangat menentukan keberhasilan dalam penegakan hukum pidana terhadap kejahatan pemanfaatan ruang laut secara menetap tanpa izin yang merupakan kejahatan terorganisir yang memiliki jaringan yang sangat luas.

Kendala selanjutnya adalah masalah pengumpulan alat bukti. Berbicara mengenai masalah pembuktian yang dianut oleh hukum pidana Indonesia adalah sistem negatif (negative wettelijke stelsel) yang merupakan gabungan dari sistem bebas dengan sistem positif. ${ }^{6}$ Pada sistem negatif Hakim hanya boleh menjatuhkan pidana terhadap terdakwa apabila berdasarkan bukti bukti yang sah menurut hukum sehingga Hakim mempunyai keyakinan bahwa terdakwalah yang telah bersalah melakukan tindak pidana. Hal ini berdasarkan ketentuan Pasal 183 UU No. 8 Tahun 1981 KUHAP, yang menyatakan bahwa: "Hakim tidak boleh menjatuhkan pidana kepada seorang kecuali apabila dengan sekurang kurangnya dua alat bukti yang sah ia memperoleh keyakinan bahwa suatu tindak pidana benar benar terjadi dan bahwa terdakwalah yang bersalah melakukannya”. Ketentuan tersebut juga menjadi dasar bagi penyidik untuk menentukan bahwa bukti yang terkumpul sudah cukup. Sulitnya mengumpulkan alat bukti dalam tindak pidana pemanfaatan ruang laut secara menetap tanpa izin menyebabkan penyidikan memakan waktu yang lama dan sedikit berbelit belit.

Pembuktian terhadap tindak pidana pemanfaatan ruang laut secara menetap tanpa izin yang masih mengacu pada KUHAP seperti tersebut diatas, adalah merupakan

\footnotetext{
${ }^{6}$ Erdianto Effendi, Hukum Pidana Indonesia, PT Refika Aditama, Bandung, 2017, hlm 129
} 
kewajiban penyidik dan penuntut umum untuk membuktikan sangkaannya terhadap tersangka, kemudian alat alat bukti yang juga mengacu pada KUHAP seperti halnya tindak pidana biasa, sangat sulit untuk menjerat pelaku pelaku yang berada di belakang kasus tersebut. Belum diaturnya mekanisme proses untuk mengakses alat alat bukti seperti akses informasi pada bank atau ketentuan yang memerintahkan kepada bank untuk meblokir rekening tersangka sebagai pemodal dalam pengelolaan tersebut yang diduga sebagai pelaku tindak pidana.

Kurangnya Wawasan dan Integritas Para Penegak Hukum dalam penegakan hukum tindak pidana pemanfaatan ruang laut secara menetap tanpa izin. Salah satu faktor yang sangat menentukan dalam penegakan hukum terhadap tindak pidana pemanfaatan ruang laut secara menetap tanpa izin adalah adanya wawasan dan integritas para penegak hukum terutama menyangkut penguasaan hukum materil dan formil, hal ini dikarenakan begitu cepatnya perkembangan masyarakat yang semakin moderen, telekomunikasi dan teknologi sehingga banyak kejahatan baru yang bermunculan dengan jenis dan modus operandi yang baru dan beraneka jenis, termasuk kejahatan tindak pidana pemanfaatan ruang laut secara menetap tanpa izin. Adanya perkembangan jenis maupun modus operandi suatu tindak pidana harus dibarengi dengan peningkatan wawasan dan integritas para penegak hukum agar tidak salah dalam menerapkan hukum dan dapat menegakkan hukum dengan sebaik baiknya. Dalam prakteknya penulis menemukan wawasan dan integritas para penegak hukum ternyata masih sangat kurang dan perlu dilakukan peningkatan lebih lanjut lagi.

\section{KESIMPULAN}

Penegakan Hukum Terhadap Tindak Pidana Pemanfaatan Ruang Laut Secara Menetap Tanpa Izin Oleh Ditpolairud Polda Sumbar adalah dengan cara melakukan penyidikan terhadap perbuatan pidana yang disangkakan melanggar ketentuan Pasal 49 dan pasal 75 Undang-Undang Republik Indonesia Nomor 32 tahun 2014 tentang Kelautan yaitu pemanfaatan ruang laut secara menetap tanpa izin. Aturan ini di Sumatera Barat didukung dengan Peraturan Gubernur Sumatera Barat Nomor 51 tahun 2018 Tentang Tata Cara Pemberian Izin Lokasi Dan Izin Pengelolaan Perairan Pesisir, Karena ketentuan tindak pidana kelautan yang terdapat dalam undang undang kelautan harus di dukung oleh berbagai peraturan daerah sebagai pelaksanaannya.

\section{DAFTAR PUSTAKA}

\section{Buku-Buku:}

Bakamla, Pokok-pokok Pikiran Tentang Keamanan Laut, Markas Besar TNI Angkatan Laut, Jakarta, 2002.

Didik Heru Purnomo, Pengamanan Wilayah Laut Indonesia, Jurnal Hukum Internasional, Desember 2004.

Dicky R Munaf, Kajian Sistem Operasi Tersinergi Bakamla Sesuai Undang-Undang Nomor 32 Tahun 2014 tentang Kelautan 2015, Jurnal Sosioteknologi, KKIK ITB, Bandung, 2015. 
Evi Banowati, Geografis Indonesia, Ombak, Jakarta, 2015.

Erdianto Effendi, Hukum Pidana Indonesia, PT. Refika Aditama, Bandung, 2017.

Raida L. Tobing dan Sriwulan Rios, Penegakan Kedaulatan dan Penegakan Hukum Di Ruang Udara, Jurnal Penelitian Hukum De Jure, Asosiasi Peneliti Hukum Indonesia, Vol 01 N0. 2, 1998.

\section{Peraturan Perundang-Undangan:}

Undang-Undang Republik Indonesia Nomor 32 tahun 2014 tentang Kelautan.

Undang-Undang Republik Indonesia No. 27 Tahun 2007 tentang Pengelolaan Wilayah Pesisir dan Pulau-Pulau Kecil.

Peraturan Gubernur Sumatera Barat Nomor 51 tahun 2018 Tentang Tata Cara Pemberian Izin Lokasi Dan Izin Pengelolaan Perairan Pesisir. 